\title{
Başkurt Destanlarında Kahramanların Olağanüstü Doğumu
}

\section{The Extraordinary Birth of the Heroes in the Baskurt Epics}

\author{
Mehmet Emin Bars a,*

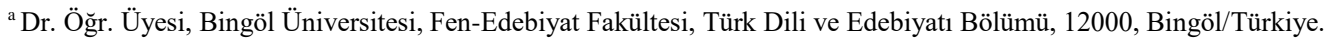 \\ ORCID: 0000-0001-6972-6860
}

\section{MAKALE BILGIISİ}

\section{Makale Geçmişi:}

Başvuru tarihi: 14 Ağustos 2017

Düzeltme tarihi: 16 Ocak 2018

Kabul tarihi: 07 Şubat 2018

\section{Anahtar Kelimeler:}

Başkurt

Destan

Kahraman

Doğum

\section{A R T I C LE INFO}

\section{Article history:}

Received 14 August 2017

Received in revised form 16 January 2018 Accepted 07 February 2018

\section{Keywords:}

Baskurt

Epic

Hero

Birth
ÖZ

Kabile hayatının egemen olduğu eski dönemlerde çocuk sahibi olmak, düşmana karşı çok ve güçlü olmak anlamına gelmekteydi. Sürekli savaşların olduğu, yaşamın büyük bölümünün akınlarda geçtiği toplumlarda, çocuk toplumsal bir beklenti halindedir. Türk destan geleneğinde kahramanların olağanüstü doğumları sabit bir kural olarak görülmektedir. Çalışmamızda Başkurt destanlarından mitolojik, sosyal hayat, han ve beylerin zamanı ile tarihî-kahramanlık konularını içeren destanlarda anlatıya ismini veren kahramanların doğumu incelenmiştir. Başkurt destan kahramanlarının bir kısmı 1şıktan doğma, iyeler tarafından müjdelenme, ağaçtan doğma, ölen anneden doğma gibi olağanüstü biçimde dünyaya gelmektedir. Kahramanların olağan dışı doğumları onların gelecekte göstereceği başarıların da habercisidir. Kahramanlar, Tanrı'dan kut alarak Türk milletini yüceltmek için yeryüzüne gönderilmiştir. Başkurt destanlarındaki kahraman tipi birçok yönden Türk destanlarında yer alan kahraman modeli ile uyum göstermektedir.

\section{A B S T R AC T}

In ancient times when the tribal life was dominant, the child meant to be strong against the enemy. In a society where there are constant wars, and a large part of life is in flocks, the child is in a social expectation. In the Turkish epic tradition, extraordinary births of heroes are seen as a fixed rule. In our study, the birth of the hero, who gave the title to the narrative in the epics that include mythological, social life, khan's time and historical-heroic issues from the Baskurt epics, was examined. Some of the Baskurt epic heroes come to the world in extraordinary ways, such as being born of light, good news by spirits, born of trees, born of a dead mother. The unusual births of heroes are also indicative of their future success. The heroes were sent to the earth to glorify the Turkish nation by receiving sacrifice from God. The heroic type in Baskurt epics is consistent with the heroic model in Turkish epics from many directions.

\section{Giriş}

Başkurtlar, Ural dağlarının kuzey ve doğu bölgelerinde İdil ırmağının kuzeye bakan havzalarında yaşayan Türk boyudur. Başkurdistan, yaşadıkları sahanın adıdır. Başkurtlar, zengin bir destan külliyatına sahiptir. Başkurt destanlarında, Başkurt Türklerinin hayatında yer alan önemli tarihî, siyasî, sosyal ve dinî olaylar yer almaktadır. $\mathrm{Bu}$ destanlar Başkurtların tarihî geçmişlerinin sonucunda oluşmuş ve gelişimini günümüze kadar devam ettirmiştir. Başkurt destanlarında eski dönemlere ait çok sayıda motif bulunmaktadır. $\mathrm{Bu}$ motifler, destanların çok eski dönemlerden tabakalaşarak günümüze ulaştığını göstermektedir.

Başkurt destan anlatıcılarına "yırav, yırcı, sesen, kumızcı, akın, kuraycı” gibi adlar verilmektedir.

\begin{abstract}
"Başkurt destanlarının yaratıcısı ve yaşatıcıları 'sesen' adı verilen millî anlatıcılardır. Sesenler sayesinde, Başkurt Türklerinin varoluşlarından bu yana şekillenen bütün maddi-manevi kültürel mirası, destan sanatı vasitasıyla günümüze taşınarak varlı̆̆ını korumaya devam etmiştir. Sesenlerden başka; Başkurt Türkleri arasında yırcı, kumızcı,
\end{abstract}

\footnotetext{
* Sorumlu yazar/Corresponding author.

e-posta: m_e_bars_21@hotmail.com
} 
akınlar ve kuraycı sıfatıyla anılan kişilerin de, destan ve diğer sözlü edebiyat verimlerinin saklanması ve yaşatılmasında önemli işlevleri söz konusudur" (Kara Düzgün, 2007: 11).

Destanların oluşum ve günümüze kadar ulaşmalarında bu destan anlatıcılarının büyük katkısı bulunmaktadır. Destan anlatıcıları, destanlarını oluştururken veya aktarırken onlara kendi hayal güçlerini katmış; olayları olağandışı unsurlarla süslemiştir. Bu tür motiflerin ayrıştırılmasıyla destanlarda Başkurtların tarihi ile ilgili önemli bilgilere de ulaşmak mümkündür. Sesenler, Başkurt Türklerinin sözlü edebiyatında XVI-XVII. yüzyıllarda cıravların takipçisi olarak ortaya çıkmışlardır. Azerbaycan ve Anadolu sahası Oğuz Türklerindeki ozanların âşık; Kıpçak Türklerindeki cıravların akın adını alması gibi, aynı yüzyıllarda Başkurt yıravları da sesen adını almaya başlamışlardır. Destanlarda Başkurtların bütünleşme mücadeleleri, Ural-Orta Asya ilişkileri, Ural'a gelişleri ve kabile damgaları gibi birçok bilgiye ulaşılmaktadır. Konularını Başkurt Türklerinin sosyal hayatından alan ve daha çok tarım, hayvancılık ve avcılıkla ilgili olan destanlara "irtek" adı verilmektedir. Destanlarda Başkurt Türklerinin yabancı istilacılara karşı verdikleri mücadeleler veya kendi aralarındaki boy mücadeleleri anlatılır.

Başkurt destanlarında mitik unsurlar yoğun biçimde kullanılır. Destanlar nazım-nesir karışık bir yapıya sahiptir. Bazı destanların büyük bir bölümü nazımdır. Tamamen nesir halinde olan destanlar da vardır. Yırav ve sesenler, destanın nesir kısımlarını tahkiye, nazım kısımlarını ezgili bir şekilde terennüm etmektedirler. Orta dönemde teşekkül eden destanlarda daha gerçekçi bir yaklaşım sergilenirken eski dönem destanları yoğun biçimde mitolojik motiflerle örülmüştür. Başkurt destanları, Başkurt Türklerinin tarih sahnesine çıktıkları günden beri onların dünyaya bakış tarzını, millet olma bilincini teşkil eden fikrî ve manevî şuurunu ortaya koymaktadır. Bütün destanlarda sosyal hayata dair önemli mesajlar bulunmaktadır. Destancılar, bir musiki aleti eşliğinde ve irticalî olarak destanlarını anlatır. Destanlarında, çeşitli toplumsal konuları da yeri geldiğinde türlü toplantılarda dile getirirler. Destancılar kötülükleri yeren, adaleti savunan, halkın sevinç ve kederlerini dile getiren, toplumun saygın kişileridir. Halkın sosyal hayatında destancıların önemi büyüktür. Eski Başkurt destancılarının adları zaman içerisinde unutulmasına rağmen, terennüm ettikleri destanlar yüzyıllarca sözlü edebiyatta varlığını devam ettirmiştir. Yırav ve sesenler Başkurt Türklerinin tarihini, bahadırların zaferlerini dile getirmişlerdir. Onlar sadece destan terennüm etmemişler, halkın ve hanların danıșmanı, toplumun bilge kişisi (özellikle yıravlar) olmuşlardır.

Başkurt destanları konuları bakımından birçok tasnife tabi tutulmuştur. $\mathrm{Bu}$ tasniflerden biri de Muhtar Sagitov tarafından şöyle yapılmıştır (Sagitov, 1998'den aktaran: Kara Düzgün, 2007: 9):

(i) Uruk cemiyetinin dağılışını yansıtan destanlar:

- Mitolojiye dayanan kahramanlık destanları ya da kobayırlar; Ural Batır, Akbozat.

- Hayvancılığa bağlı sosyal temalı ve aile kuruluşu hakkındaki kobayırlar ve hikâyeler; Akhak Kola, Kunır Boğa, Kara Yurga, Zayatülek ile Hıvhılıv.

(ii) Feodalizmin başlangıç dönemini yansıtan destanlar:
- Uruk-kabile huzuru ve beraberliği idealini öne çıkaran, bu bağlamda sosyal ve aile münasebetlerini anlatan hikâyeler; Alpamışa, Kuzıykürpes ile Mayanhılıv, Zöhre ile Adlar.

- Uruklar arası mücadeleleri yansitan destanlar; Küsek Bey.

(iii) Feodalizmin gelişme dönemlerini yansıtan destanlar; İzevkey ile Morazım, Mergen ile Mayanhılıv, Targın ile Kujak, Yek Mergen, Bozyiğit.

(iv) Feodalizmin son dönemini yansitan destanlar ve hikâyeler; Karas ile Akşa, Teyiş Mergen, Salavat Batır, Bayık-Ayzar Sesen.

\section{Türk Düşüncesinde Destan Kahramanları}

Türk destan sanatı konu, tip ve yapı itibariyle bir bütünlük arz etmektedir. Türk destanları arasında organik bir bağ bulunmaktadir.
"Bu organik bağ, Türk destan geleneğini konu, tip, motif ve kusmen şekil olarak bir bütün olarak anlamamızı ve Türk destan geleneği araştırmalarını bu tespit çerçevesinde değerlendirmemizi zorunlu kllar. Bu zorunluluk her milletin epik sanat araştırmalarında olması gerektiği gibi, Türk destan geleneğine ait unsurların incelenmesinde, Türk milletinin varoluşundan bu yana geçirmiş olduğu dinî, iktisadi, sosyal, askeri ve benzeri birçok merhaleleri bilmemizi gerektirir" (Kara Düzgün, 2007: 118).

$\mathrm{Bu}$ merhaleleri bilmek çeşitli katlardan oluşan destanların içindeki sırları öğrenmemizi sağlar.

Türk inanış sistemi, Türk destan geleneğinde bulunan tipleri şekillendirir. Türk milleti kendi yaratılış ve yaşayış şartları gereği bir töre oluşturmuştur. Türk destanlarındaki kahraman tipi de, Türk töresine göre şekillenmiştir. Bundan dolayı Türk destan kahramanı tipi ile toplum arasında sıkı bağ bulunmaktadır. Töre, milletin ve o millete ait fertlerin ideal örneklerini belirler. Destan kahramanları da milletlerin ideal insan tipini ortaya koyar. Millete ait bütün maddi ve manevi olgular törede yer almaktadır. Destan kahramanı, millî birlik anlamına gelen törenin koruyucusudur.
"Toplumsal değerler açısından doğru ve haklı kabul edilen eylemleri gerçekleştiren ve dolaylsıyla haklı tarafta yer alan, eylemlerini şahsî olmaktan öte toplum yararına gerçekleştiren destan kahramanı, yaptığl hareketin amacı hususunda kararl ve sorumluluk duygusuna sahip bir kişidir. Destan kahramanları, toplumsal değerler adını verdiğimiz ve milletin ortak hafizasinda saklanıp nesilden nesile aktarılan değerlerin dile getiricisi, uygulayıcısı rolündedir" (Sever, 2011: 196).

Bir millet ülkülerini, hayat felsefesini, inançlarını üstün vasıflarla donatılmış kahramanlarında aksettirir. Onlar toplumun örnek kişileridir. Destan kahramanları halkın desteğini alan, Türk töresini yaşatan, seçkin kişilerdir. Bu kişiler halkın onlara en çok ihtiyaç duyduğu dönemlerde ortaya çıkar. Bu dönemler törenin bozulduğu, millî birliğin tehlikeye düştüğü zamanlardır. Millî birliğin yeniden kurulması için halk, güçlü ve donanımlı bir lider arar. Destan kahramanları halkın bu ihtiyacına cevap vermek için tam da 
bu dönemlerde sahneye çıkar. Halk her bakımdan olağanüstü özelliklere sahip bu kahramanların etrafında birleşir.

Destan kahramanı, halkına karşı tehdit unsuru olan her türlü iç/dış düşmanlar ile savaşır. Millet kendi ideal ve ilkelerine göre bir kahraman tipi yaratmış, onu yüksek karakter ve kudret ağıyla donatmıştır. Türk destan kahramanı kutsal bir kişiliğe sahiptir. Kahraman kutsal güçlerin yardımıyla ya da onlar adına halkı için savaşır. Türk milleti, yüce Tanrı ile kendi yarattığı kahraman tipi vasitasıyla bağlantı kurmaktadır. Kahramana Tanrı tarafından kutsallığını ifade eden "kut" verilmiştir. Tanrı'nın kutuna nail olan kahraman, milleti adına her işin üstesinden gelmektedir. Destanlarda kahramanın olağanüstü doğumu, büyümesi gibi motifler onun kutsal hüviyetinin sonucudur. Tanrı tarafından kut verilen kahraman ile içinde doğup büyüdüğü halk iç içedir.

Destan kahramanları çoğu zaman kağan, han olarak görülmektedir. Tanrı kâinatı, kendi iradesiyle yaratan en büyük ve tek varlıktır.

"Onun yaratması kozmosun teskilidir ve onun yer yüzünde kurmuş olduğu düzenin koruyucularl, bizzat Tanrı'nın yer yüzündeki halifeleri olan kağanlardır. Üstte Tanrl, altta devlet ve onun başındaki kağan yer almaktadır. Kağanlar bizzat Tanrl tarafindan gönderilmiştir ve onlar ulusu koruyup yücelterek kozmosun (törenin) devamlılığını sağlarlar” (Aça, 2002: 158).

Bu durumda kağana veya devlete başkaldıran kişi, Tanrı'ya baş kaldırmış olacaktır. Tanrı, Türk ulusu yok olup tükenmesin diye kağanları (kahramanları) göndermiştir. Ancak, kağan töreye uymazsa, Tanrı kutunu ondan geri alacaktır. Kağanla beraber halkı da zelil olacaktır.

\section{"Türk destanlarında bulunan geniş Asya steplerinin zorlu iklim şartlarl, kendi aralarında ve düşmanlarıyla yaptıkları savaşlar, sık sık yıkılıp kurulan devletler, göçebe bir hayat tarzını zorunlu kllmıştır. Böyle bir yaşam da kahramanlık ve cengâverlik ruhunu beraberinde getirmiştir. Göçebe hayatın tüm zor koşullarında hayatta kalmaya çalışan insan, doğanın kendisine verdiği yetenekleri geliştirmek zorundadır. Bu durum Türk destanlarında kahraman 'alp tipi'ni doğurmuştur” (Bars, 2014: 347-348).}

Destan kahramanlarının hemen hepsi destanlarda aynı zihniyetle hareket etmektedir. Düşünüş, duyuş, mücadele, yaşayış, güç, cesaret gibi vasıflar bütün Türk destan kahramanlarında hemen hemen aynı çizgidedir. Bütün Türk destanlarında mutlaka olayların etrafında döndüğü bir kahraman bulunur. Destan kahramanı milletin düşünce ve ideallerinin sözcüsüdür. Destanlardaki olaylar, yerler, tarihler değişirken, ortak ülkü aynı kalmıştır. Bundan dolayı her destan kahramanı, bir önceki destanın kahramanı ile birçok ortak paydada buluşmaktadır. Destan kahramanı milletin geçmişini şekillendirdiği gibi geleceğine de yön vermektedir. Kahramanın her davranışı, verdiği her karar toplumun gelecek nesilleri için esin kaynağıdır. Bir kahramanın şahsında idealize edilen ülküler, destanın diğer bölümlerinde kahramanın yerini alan şahıs tarafından da devam ettirilir. Kahramanlarda kendi menfaatlerin yerine toplum menfaatleri, inanılan dünya görüşünün fikirleri için kendini feda etme duygusu hâkimdir.
Kahramanlar (alplar), süreğen savaş şartlarında yaşayan göçebe boylarda önderlik ve savaşçılık yetenekleriyle toplumun önde gelen kişileridir. İyi binici olan kahramanlar, savaş aletlerini çok iyi kullanır ve savaşlarda kişisel kahramanlıklarını sakınmadan sergiler. Uzun boylu, bahadır ve güçlüdürler.

"Ozanlık yeteneklerini haiz olanlarl vardır. Kadınlar tüm bu özellikler açısından erkeklerden geri kalmaz. Konfederasyon şartlarında bir alpın çevresinde daha alt düzeyde alplar toplanır. En üstteki alpla bağımlı alpları arasında gelişigüzel olmayan ve bir hukuka dayanan ilişkiler sistemi vardır. Büyük alp belli zamanlarda bağımlıları toplamak ve bu toplantılarda ziyafetli şölen düzenlemek zorundadır" (KaratayAygün, 2012: 3).

Buna göre alplar arasında güçlerine göre bir hiyerarşi vardır. Bağımlı alplar, üstte bulunan büyük alpa tabidir.

\section{Başkurt Destanlarında Kahramanların Doğumu}

Doğum, evlilik ve ölüm insan hayatının önemli geçiş evreleridir. $\mathrm{Bu}$ evreler zihnin geride bırakılan aşamanın alışkanlıklarından, bağlarından ve yaşam düzenlerinden kesin biçimde koparıldığı dönemlerdir. Bir çocuk, yetişkin bir birey olarak toplum içindeki varlığını ispatlama sürecinde söz konusu geçiş evrelerinde gösterdiği başarıya göre değerlendirilir.

Türk kültüründe aileye büyük önem verilmektedir. Aile, topluma fert kazandıran önemli bir sosyal yapıdır. Toplum, varlığını aile müessesesi ile sürdürür. Çocuk ile aile, soyun ve toplumun devamlılığını sağlar. Özellikle kabile hayatının egemen olduğu eski dönemlerde çocuk sahibi olmak, düşmana karşı çok ve güçlü olmak anlamına gelmekteydi. Sürekli savaşların olduğu, yaşamının büyük bölümünü akınlarda geçiren toplumlarda çocuk, toplumsal bir beklenti halindedir. Savaşçı-akıncı toplumlar çok zor şartlar altında varlıklarını sürdürmeye çalıştıklarından ötürü, bu toplumların devamlılıkları genç nesillerin enerjisine ihtiyaç duymaktadir.

Toplumda özellikle yiğit veya lider konumunda olan kişilerin çocuğunun olmaması bir eksiklik, toplum tarafindan eleştirilen ve göze batan bir durum olarak görülmüştür. $\mathrm{Bu}$ kişiler Tanrı'nın kendilerine kut verdiği seçkinlerdir. Bu kişilerin çocuk sahibi olamamaları, halkta hoşnutsuzluk yaratmıştır. Kutlu kişilerin çocuk sahibi olamamaları Tanrı tarafından verilen kuta duyulan saygıda şüpheler oluşturmuştur. Tanrı tarafindan gönderildiğine inanılan kahraman veyahut hanların çocuğunun olması kutlu döneminin devam edeceği anlamına gelmektedir. Halk, kutlu kişilerin çocuklarından da babalarına benzer başarılar beklemektedir. Çünkü bu çocuk, kutlu soyun devamıdır. Kut baba tarafından çocuğuna geçecektir, kutlu çocuk halkın yeni koruyucusu olacaktır. Nitekim erginleşmeye başlayan çocuk, soyuna has özelliklerini eylemleriyle ya da taşıdığı bir takım olağanüstü yetenekler vasıtasıyla göstermelidir. Aslında bu sıra dışı özellikler, daha kutlu kişinin doğumuyla kendisini göstermiştir.

"Kahramanın hayat macerasl, umumiyetle yaşlı bir ana-babadan efsânevî doğuşu ile başlar ve bunu, kahramanın olağanüstü gelişme devresi ile takip eder" (Yıldırım, 1998: 150). 
Kahraman sıradan toplum bireylerinden farklı bir şekilde olağanüstü doğumu ile kutlu bir kişi olduğunu ilk başta göstermiştir.
"Destan
kahramanlarının
doğumundaki
olağanüstülükler sadece onun doğumundaki ve gelişimindeki süreçle ilgili olmayıp doğum öncesindeki birtakım hazırlıklarla da bağlantılıdır. Çocuksuz ve yaşı geçmiş bir anne-babanın adă̆ duası, rüyada gördüğü derviş veya dervişin verdiğ $i$ bir şey ile kahramanın anne rahmine düşmesi gerçekleşir” (Kalkan, 2016: 30).

Dede Korkut anlatılarından Dirse Han'ın çocuk sahibi olması, büyük bir toy düzenleyip açları doyurması, fakirleri giydirip borçluları borçtan kurtarması ve ağzı dualıların duaları sayesinde gerçekleşmiştir. Kahramanın doğumuyla başlayan farklılık büyümeyle beraber halk nazarında göstereceği başarıyla kanıtlanmış olacaktır. Bunu kanıtlamak kahraman için şarttır. Çünkü kutlu soyun devamı da olsa, halk nazarında başarı göstererek itibar sahibi olamamış bir kahraman ya da hana kimse itibar etmeyecektir.

\begin{abstract}
“... Türk destanlarının olumlu, alperen tipi destanlarımızın çoğunda daha ana rahmine bile düşmeden 'olağanüstü' yani Tanrı veya 'tanrisal' güçler tarafindan benzer kabiliyet ve güçlerle donatılmaya başlanması, -ki en başta varlıkların bağışlanması, adak olmaları gelir- nedeniyle ve doğumlarından itibaren bir veya birkaç günde büyümek, süt yerine, et, ekmek, su, şarap-kımız istemek, kısa zamanda konuşmak, henüz bebek beşiğinde yatarken 'gelecekte yapacaklarl büyük fütuhatın haberini vermek' gibi olağanüstü yeteneklerle ve hedeflerle doğarlar" (Çobanoğlu, 2007: 105).
\end{abstract}

$\mathrm{Bu}$ olağanüstü doğum kutlu soyun devamının da bir habercisidir.

Kahramanların doğumunda görülen olağanüstülükler "Tanrığlu motifi" (Bayat, 2006:139) ile ilgilidir. Türk destan geleneğinde kahramanların olağanüstü doğumları sabit bir kural olarak görülmektedir. $\mathrm{Bu}$ durum kahramanların bir misyon ile doğduklarının işaretidir. Türk anlatılarında peygamber, veli, hakan, destan kahramanı ve şaman gibi olağanüstü özelliklerle sahip kişilerin birtakım tanrısal simgelerin (1şık, nur, kan, kanlı abdest suyu, buğday tanesi, et parçası, buz parçası, vs.) yardımıyla dünyaya geldikleri görülmektedir.

\begin{abstract}
"Normal insanlara göre ana rahmine düşüşşartlart çok farklı olan 'kahramanlar', dünyaya gelmelerinde etkili olan tanrisal simgeler dolayısıla içine doğdukları toplumu yerine göre uyarma, onları çeşitli saldırllardan koruma, esir iseler özgürlüklerine kavuşturma gibi görevleri ifa etmekteler. Bir başka ifadeyle, söz konusu kahramanlar, içine doğdukları toplumun niteliğine bürünerek o toplumun hürriyetine, kurtuluşuna ve kutsanmasina vesile olmaktalar" (Bekki, 2011: 122).
\end{abstract}

Edige Destanı gibi bazı anlatılarda kahramanın dünyaya gelişi ve hayatta kalışı açısından olağanüstü bir soy ağacı ile karşılaşırız. Edige'nin atası Baba Tükles adlı bir veli veya evliya tipidir. Anası ise bir peri kızıdır. Bu tür kahramanlara, olağanüstü yeteneklerinden dolayı eski hikâye metinlerinde "perizad" sıfatı verilmiştir (Kalafat, 2003: 348). Çocuk hem beşerî ve hem de insanüstü bir varlıktır. Her iki meziyete aynı zamanda sahiptir. Destan kahramanlarında görülen ağır ve tabii olmayan bir şekilde uzun süreli doğum, ileride kahraman olacak bir bebeğin dünyaya geleceğini haber vermektedir.

Anlatılarda çocuksuzluk motifi çeşitli temalarla zenginleştirilir.

"Türk destan geleneğinde, 'çocuksuzluk' olarak adlandırlan motif, kahramanın babasinın bir bey olması, çok mal-mülke sahip bulunması, bir veya birçok eşi olmasına ră̆men bir çocuğa sahip olamayışı, çocuğun haberinin mucizevi bir şekilde verilmesi, şartlı olarak bağışlanması gibi temalarla zenginleştirilir. İleri yaşlardaki anne ve babadan dünyaya gelme, bu kahramanın başka alternatifinin olamayacağını; dolayıslyla önemini vurgulamak için destancının kullandı ̆̆ bir yoldur”'(Y1ldız, 2009: 87).

Sıra dışı doğum, sıra dışı bir kişiliğin oluşacağının da ilk işaretidir.

İnsanın ruh dünyası doğmadan önceki şartların etkisinde bulunur. Bazen kahramanın doğmadan önceki şartları, bazı olağanüstü problemlerle doludur. S.Freud, bu durumu "iki dönemli gelişme nazariyesi" olarak değerlendirir. Bu, "büyük bir olay (ilk dönem) -uzun süreli gizli dönem- bir olay nedeniyle döneme geri dönme ve kahramanın ortaya çıkması" olarak açıklanır. Freud'a göre kahramanın halledilen problemlerinin temelinde uzak geçmişte atalarımız tarafından çözülmeyen problemler yatar. Mevcut döneme ait problemler yüzeyseldir; onların temelinde eskiden beri var olan sebepler yatar. Günümüzde karşımıza çıkan problemler, geçmiş zamanların çözülemeyen problemlerinin bir sembolüdür. Kahramanın doğumu, daha önce yaşayan ataları ile bağlantılıdır. Jung'a göre, kahramana vazife veren güç grup psikolojisidir. Grup psikolojisi insanlık tarihinin başlangıç döneminde ortaya çıkmış, nesilden nesile aktarılmıştır. Lacan bunu "Büyük Ötekiler" olarak adlandırır. Büyük Ötekiler, insanın bilinçaltında çocukluk dönemindeki ataları, anne-babası, örf-âdetleri, sembolleri ifade eder. Bunlar gerçekten yaşamayan, sadece bilinçte olan yabancıların bıraktığı mirastır ve toplum tarafindan korunan istekler kahramanın ruh dünyasını etkiler (Oh, 2011: 158).

$\mathrm{Bu}$ açıklamalar ışı̆̆ında kahramanların maceraları ile ilgili tehlikeli durumları ortaya çıkaran olayların, sadece günümüze ait olmadığı söylenebilir. $\mathrm{Bu}$ problemler kahramanın doğumundan önce, uzun süre boyunca sessiz ve gizli hâlde beklemiş; kahramanın doğumuyla beraber daha da büyüyerek karşısına çıkmıştır. Destan kahramanının ortaya çıkmasına eski dönemlerde yaşayan atalarını sarsan birtakım olaylar neden olmuştur. Toplum tarafindan çözülemeyen, üstesinden gelinemeyen büyük ölçekli olayları çözecek bir kahramana ihtiyaç duyulmuştur. Kahraman bu olağanüstü durum karşısında ortak toplumsal bilincin şekillendirdiği ihtiyaçla ortaya çıkmıştır. Her milletin düşünme şekli, atalarından miras kalan bilinçaltı düşüncelerinin etkisiyle şekillenir. Destanlarda da destanı yaratan ve bu destanın özünü halkın manevî dünyasına taşıyan kabilenin bilinçaltı hisleri bulunmaktadır. 
Dinler tarihinde en şöhretli doğum hadisesi Hz. İsa'nın dünyaya gelmesidir. Kuran-1 Kerim'de, Meryem suresinin 16-30. ayetleri bu konuya ayrılmıştır.

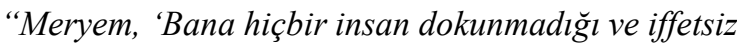 bir kadın olmadığım hâlde, benim nasıl çocŭ̆um olabilir?' dedi. Cebrail, 'Evet, öyle. Rabbin diyor ki: O benim için çok kolaydır. Onu insanlara bir mucize, katımızdan bir rahmet kılmak için böyle takdir ettik. Bu, zaten (ezelde) hükme bağlanmış bir iştir' dedi. Böylece Meryem, çocuğa gebe kaldı ve onunla uzak bir yere çekildi" (Meryem/20-22).}

Çocuğu olmayan Hz. İbrahim'in Allah'a dua ederek bir çocuk istemesi ile bir erkek çocuğunun olması ve oğlu İsmail'i kurban etmesi gerektiğinin söylenmesi çocuksuzluk motifinin dinî metinlerdeki bir diğer yansımasıdır (Kayabaşı, 2016: 132-133). Türk destanlarında kahramanların olağanüstü doğumunda genellikle şu motifler karşımıza çıkar (Kara Düzgün, 2007: 136):

(i) Kahramanın doğumu önceden müjdelenir. (Çocuksuzluk motifi)

(ii) Kahraman olağanüstü şartlarda doğar. (Bu doğum ilahî bir oluşum sonucunda vuku bulur.)

(iii) Kahraman, Tanrı katından gönderilmiştir ve genellikle soylu bir aileye mensuptur.

(iv) Kahraman genellikle tek çocuktur. (Bazen en büyük ya da en küçük çocuk olarak da ortaya ç1kabilmektedir).

Bu çalışmada Başkurt destanlarından mitolojik, sosyal hayat, han ve beylerin zamanı ile tarihî-kahramanlık konularını içeren 84 destan metni incelenmiştir. $\mathrm{Bu}$ metinlerin bazılarının farklı varyantları da kullanılmıştır. İçinde birkaç sayfalık kısa destan parçaları olan metinlerle birlikte uzun hacimli olanları da vardır. $\mathrm{Bu}$ destanlarda sadece anlatıya ismini veren kahramanın doğumu incelenmiştir. İncelenen destan metinlerinin çokluğuna bakıldığında Başkurt destanlarında kahramanların doğum motifi üzerinde, destandaki tüm olaylar düşünüldüğünde, fazla durulmadığı görülmüştür. Metinlerde kahramanların doğumları şu şekilde yer almaktadır:

\section{1. İyeler Tarafından Çocuk Verilmesi}

Alıp Batır Destanı'nda kahraman doğumundan önce müjdelenir (Süleymanov vd., 2014a: 327-328). Destanda çok eski zamanlarda Ak İdil Nehri boyunca bir ata ile bir ana yaşar. İhtiyarların çocukları olmaz. Her ikisi de bu duruma çok üzülür. Ata ok ve yayına alarak ava çıkar. Bir dağın eteğinde uykuya dalar. Düşünde dağın iyesi ataya görünür. Dağ iyesi atanın üzülmesinin nedenini sorar. İhtiyar, çocuğu olmadığ için üzüldüğünü söyler. Dağ iyesi bir can ölmeden diğer canın gelmeyeceğini söyleyerek oğlunun olmasını istiyorsa bu dünyayla vedalaşmasını söyler. İhtiyar razı olur. Dağ iyesi taşın arkasına girip kaybolur. İhtiyar uyanınca, başının altına koyduğu taşın hareket ettiğini görür. Taşı kırar, taşın içinden bir yiğit çıkar. Yiğit ona oğul olarak geldiğini söyler. Yiğit çok yakışıklı ve dev vücutlu birisidir. Ata kısa süre sonra orada ölür. Bu anlatıda kahramanın dağ iyesi tarafından müjdelenmesi ve bir taşın içinden doğması Türk destanlarında pek görülmeyen bir doğum motifidir. Bir diğer özellik ise çocuğun doğumuna karşılık babanın canının istenmesidir. Benzer motif Dede Korkut anlatılarında Deli Dumrul'un canına karşılık anne-babasından can istemesinde görülür. Ancak oradaki motif doğumla ilgili değildir. Alıp Batır Destanı'nda kahramanın doğumunda görülen yetişkin biçimde doğma diğer bir özelliktir. Kahraman taştan doğduğunda babasından daha iri vücutludur, bir yetişkin olarak doğmuştur.

\subsection{Yaşl1 Anne-Babadan Doğma}

Yaşlı anne ve babadan doğma motifi çoğu kez diğer motiflerde de karşımıza çıkmaktadır. Bu motif destanlarda en çok karşılaşılan doğum motifidir. Dağ iyesi tarafindan çocuk verilmesi ve kendi soyunun tek temsilcisi olma gibi durumlarda da görülür. Alpamışa Destanı'nda Alıp Batır Destanı'na benzer biçimde kahraman yaşlı anne ve babadan doğar (Süleymanov vd., 2014a: 361). Destanda çok eski zamanlarda bir yaşlı kadın ile ihtiyar yaşar. İhtiyarın adı Oltanbey, ninenin ismi Bike'dir. Bir zaman sonra ihtiyar Bike hamile kalır. Tarlada bir oğlan çocuk doğurur. Bebek acayip büyüktür, alt ve üstten dişleri vardır. Boyu yedi yarım arşındır. Korkan yaşlı Bike çocuğu bırakıp gitmeyi düşünür, çocuk annesiyle konuşmaya başlar. Burada annesinden doğan çocuğun normal boyutların çok üzerinde olması ve annesi ile konuşması annesini korkutmuş, anne çocuğunu doğurduğu bir ağacın altında bırakarak eve kaçmıştır.

\subsection{Soyunun Tek Temsilcisi Olarak Kahramanın Doğumu}

Uzak ile Tuzak Destanı'nda kahraman soyunun tek temsilcisi olarak görülür (Süleymanov vd., 2014a: 387-388). Kahraman daha sonra düşmanlardan soyunun intikamını alacak ve soyunu devam ettirecektir. Benzer motif türeyiş destanlarında da görülmektedir. Bu yönüyle destan yok olmak üzere olan bir soyun yeniden hayat bulmasını anlatır. Destana göre Olobeşnek beyleri, Balabeşnekleri zulümle idare eder. Balabeşnekler daha sonra Balavsaların saldırılarıyla Ural Dağı'nın eteklerine kaçar. Uruktan sadece iki yaşlı karı-koca Yenuzak ile Uralbike kalır. İki yaşlı çocuklarının olması için gece gündüz dua eder. Bir süre sonra ihtiyarların bir oğulları olur.

Yek Mergen Destanı'nda ise Ak İdil'in kenarındaki yeşil ovada Tugızak Nine dokuz oğluyla beraber yaşar (Süleymanov vd., 2014d: 67-69). Tugizak Nine namlı bir ordu başının bikesi (hanımı)dir. Tugızak Nine'nin beyi Ak Adil, bahadırlarıyla beraber sefere çıkar. Bey ondan sonra dönmez. Tugızak Nine'nin dokuz oğlu, savaşlarda büyük başarılar kazanır, kahramanlıkları dilden dile anlatılır. Bir gün dokuz bahadır uyurken, düşman hepsini öldürür. Halkını esir eder. Ancak, düşmanın geldiğini sezen en küçük gelin iki yaşındaki oğlunu kaçırmayı başarır. Kısa süre sonra obaya dönen küçük gelin de üzüntüsünden ölür. Küçük çocuk annesinin göğsünden sütünü memesi kuruyuncaya kadar emer. Çocuğa orman tavşanları doyurucu otlar getirir, nazik kuşlar onları çeşitli meyvelerle besler. Tabiat, çocuğu büyütür.

\subsection{Yaşanan Olayları Yorumlama}

Burada kahramanın anne veya babasının başından bir olay geçer, anne-baba bu olaylara bakarak çocuklarının olacağını anlar. Kuzıykürpes ile Mayanhılıv Destanı'nda Küser Han ile Küsmes Han adlı iki han yaşar (Süleymanov vd., 2014b: 55-56). Bunlar çok iyi dosttur. Birlikte ava çıkarlar. Karşılarına çıkan yollardan sağa Küser Han, sola Küsmes 
Han devam eder. Epeyce gezerler. Küsmes Han yolda bir geyiğe rastlar. Vurmak ister; ama geyik ayaklarını yere vurarak durur, memelerinden süt akar. Küsmes Han geyiğe acır, onu vurmaz. Küser Han da bir geyiğe rastlar. O da aynı şeyleri görür. Her iki han da bunu, çocuklarının olacağı şeklinde yorumlar. Bir süre sonra Küsmes Han'ın bir oğlu, Küser Han'ın bir kızı olur.

\subsection{Yapılan Dua Üzerine Doğum}

Birçok destanda çocuğu olmayan anne-baba büyük bir toy verir. Toyda fakirlerin, yaşlıların duası alınır. Bir süre sonra bu dua meyvesini verir, anne-baba bir çocuk sahibi olur. Dede Korkut kahramanlarından Dirse Han'ın da benzer şekilde bir oğlu olur. Kuzıykürpes Destanı'na göre eskiden İrtiş Irmağı'nın doğduğu yerde Başkurt uruğundan Karabay adlı bir kişi yaşar (Süleymanov vd., 2014b: 591-598). Üç karısı olan Karabay’ın bir türlü çocuğu olmaz. Avda bir arslan öldüren Karabay, toy verir. Toyda halk çocuğunun olması için dua eder. Tanımadıkları bir aksakal Karabay’a misafir olur. Aksakal, Karabay'a bir oğlunun olacağını söyler ve ortadan kaybolur. Bir süre sonra karısı Altışa bir erkek çocuk doğurur.

Koblan Batır Destanı'nda ise geçmiş zamanlarda Kara Kıpçak elinde yaşayan ihtiyar bir adamla ihtiyar karısı yaşar (Süleymanov vd., 2014d: 55). İhtiyarlasalar da bunların hiç çocukları olmaz. Kadırbay İhtiyar seksen yaşına gelince yalvararak Allah'tan çocuk diler. Hayırlı sadakalar verir; büyü ve sihir yaptırır. Kanatsız şahin, toynaksız at gibi nesilsiz-tohumsuz öleceğine çok üzülür. Nineyle dede bir düğüne gider; çoluk çocukları olmadığı için onları oturtmazlar. İhtiyarlar utançlarından düğün hediyesi olarak getirdikleri kımızlarını dökerek evlerine dönerler. Kocakarı Minhılıv, bir rüya görür. Rüyasında bir evliya ile karşılaşır. Evliya ikiz çocuklarının olacağını söyler. Hamile kalan kocakarının bir süre sonra biri oğlan biri kız ikizleri doğar. Erkeğe Koblan, kıza Kolansas adları verilir.

\subsection{Iş1ktan/Nurdan Doğma}

Cengizname'de kahramanın doğumu diğer destanlardan farklı biçimde karşımıza çıkar (Süleymanov vd., 2014c: 7074). Anlatıda Altun Han'ın Kürekle adlı çok güzel bir kızı vardır. Kız hiç saraydan dışarı çıkmamıştır. Kürekle bir gün pencereden gün ışığını görür, bu ışıtan hamile kalır. Babası halk tarafindan duyulmaması için kızını bir gemiye bindirerek, Tön Denizi'ne bırakır. Gemiyi Turnavul Mergen bulur. Bir süre sonra doğan erkek çocuğuna Tanrı'nın verdiği duyınlık (hediye) anlamında Duyın Bayan adı verilir. Benzer motif Uygur türeyiş destanında görülür. Bir gece Selenge ve Tola nehirleri arasında bulunan bir ağaç üzerine kutsal bir 1şık iner. Dokuz ay on gün sonra ağaçtaki şişkinlik çatlar, beş çocuk dünyaya gelir (Ögel, 1998: 81). Alan-Kowa 1şıklarla inen bir kurt veya arslandan hamile kalır (Ögel, 1998: 132).

\section{7. Ölen Anneden Doğma}

Aksak Timur Destanı'nda Çağatay Han bir gün kötü bir düş görür (Süleymanov vd., 2014c: 127-129). Falc1lar, Taragay'ın hanımının hamile olduğunu, onun karnındaki çocuğun hanı öldüreceğini söyler. Çağatay Han, Elmalı köyündeki Taragay'ın hamile karısını getirtip onu öldürür. Ölmüş kadın bir erkek çocuk doğurur. Oğlanın ayağı aksak olduğundan adı Aksak Timur olarak konur. Anlatıdaki doğum motifi Hz. Musa'nın olağanüstü doğumunu hatırlatır. Gördüğü rüya üzerine Mısır'da yeni doğan bütün erkek çocuklarını öldürten Firavun, yine de annesi tarafindan bir sandalla Nil'e bırakılan ve sarayda büyüyen Musa'nın tahtını yıkmasından kurtulamaz (Pala, 1995: 402). Köroğlu'nun doğu varyantlarında da ölmüş annesinden mezarda doğan çocuğa Guroğlu (mezarda doğan) adı verilir (Ekici, 2004: 106-109).

\subsection{Ağaçtan Doğma:}

$\mathrm{Bu}$ motif yukarıda belirtilen Uygur türeyiş destanında da görülür. Selenge ve Tola nehirleri arasında bulunan bir ağaç üzerine inen kutsal bir 1şık ağacın her gün şişmesini sağlamış, dokuz ay on gün sonra da ağaçtan beş çocuk dünyaya gelmiştir. Kıpçak Soylu Yamsırgı Bey ile Kuskar Bey Destanı'nda, Kıpçak ağaç kovuğunda doğduğu için kendisine Kıpçak adı verilir (Süleymanov vd., 2014c: 573).

\subsection{Doğumu Rüyada Görme}

Türk dünyası halk anlatılarında sıkça karşımıza çıkan motiflerden biri de herhangi bir olay meydana gelmeden önce onu rüyada görme motifidir. Anlatılarda rüya motifi farklı işlevlerle karşımıza çıkmaktadır. Özellikle halk hikâyelerinde âşık olmanın olmazsa olmaz bir motifi olarak görülebilir. Sura Batır Destanı'nda Narıkbay adlı bey güzeller güzeli Minhılıv ile evlenir (Süleymanov vd., 2014d: 73-75). Narıkbay, Nogayların asil soyundandır. Han, Minhılıv'a göz diker, ona saldırır; Narıkbay, Hanı öldürür, karısı Minhılıv'ı da yanına alarak kaçar. Minhılıv bir gün rüyasında ayaklarının arasından bir ateşin çıktığını görür. Ateşin bir ucu yerde bir ucu göktedir. Toplanan insanlar ateşi söndürmeye çalışır; ancak söndüremezler. Minhılıv, rüyayı bir oğlu olacağına ve ölümünün de sudan olacağına yorar. Bir süre sonra oğulları olur, ona Sura ismini verirler. Oğullarının doğmasıyla yeniden mal davar sahibi olurlar, hayvanları çoğalır, evleri barkları bereketlenir.

\section{Sonuç}

Türkler, akıncılık ve hayvancılığa bağlı göçebe hayat sürdürdükleri dönemlerde, düşmanlardan korunmak, ihtiyaçlarını gidermek gibi sebeplerle genç nesillerin yetiştirilmesine çok önem vermiştir. Toplumda neslin devamının sağlanmaması, o toplumun yok olması anlamına geldiğinden çocuk sahibi olamayanlar toplumda hakir görülmüş ve onların Tanrı tarafından cezalandırıldıklarına inanılmıştır. Başkurt destanlarında olağanüstü şartlarda dünyaya gelen kahramanlar kutlu, seçilmiş kişilerdir. Kahramanlar genellikle yurt ya da kabile içinde kaosun başladığı dönemlerde dünyaya gelmişlerdir. Destanlarda biyolojik olarak çocuk sahibi olabilecek yaşı çoktan geçen kişiler, Tanrı'ya sundukları adaklar, yaptıkları iyilikler ve bir ağzı dualının yardımı ile çocuk sahibi olmuşlardır. Böyle kutsallıklarla dünyaya gelen çocukta görülen olağanüstü özellikler onun kutunun bir gereğidir.

Başkurt destan kahramanlarının bir kısmı 1şıktan doğma, iyeler tarafinda müjdelenme, ağaçtan doğma, ölen anneden doğma gibi olağanüstü biçimde dünyaya gelmiştir. Kahramanın olağan dışı doğumu onun gelecekte göstereceği başarıların habercisidir. İnsanoğlu ideallerini gerçekleştirebilecek donanıma sahip hayalî kimlikler yaratır. Kimsenin olmadığı kadar kuvvetli ve başarılı tahayyül edilen 
bu tiplerin asil bir soydan geldiğine inanılır. Başkurt destanlarında soylu bir aileden gelen kahramanların yanı sıra, bazı kahramanların sıradan halktan çıktığı görülür. Ancak kahraman sıradan bir aileden de gelse başlı başına kut sahibi biridir. Yaradılıștan itibaren taşıdığı kut onun kahraman olması için lütfedilmiştir. O, Tanrı'nın yeryüzündeki temsilcisi olduğundan ailesi soylu olmasa da Tanrı kutunu taşıyan kimsedir. Kahraman, Tanrı'dan kut alarak Türk milletini yükseltmek için yeryüzüne gönderilmiştir.

Başkurt destanlarındaki kahraman tipi birçok yönden Türk destanlarında yer alan kahraman modeli ile uyum göstermektedir. Destanlarda kahramanların doğumlarından itibaren sergiledikleri niteliklerinden onların Tanrı katından gönderildiği anlaşılmaktadır. Toplumunun kurtuluş ümidi olarak mucizevî bir şekilde dünyaya gelen kahramanların doğumlarındaki olağanüstülük, yaptıkları işlerin sıradan bir doğumla dünyaya gelen insanlardan farklı olacağının da bir göstergesidir. Toplumun içerisinde bulunduğu koşullar, tarihî olarak kahramana duyulan ihtiyaçla şekillenir. Yaşanan coğrafyalar, inanılan dinler, destan adları, kahramanların bazı özellikleri değişse de Türk dünyası destanları ortak özünü yitirmemiş; geçirdiği bu değişimlere göre kendini yeniden biçimlendirerek orta kökene dayanmıştır.

\section{Kaynakça}

Aça, M. (2002). Türk Destancılık Geleneğine Bütüncül Yaklaşabilme ve Alp Kavramı Üzerine Bazı Yeni Yaklaşım Denemeleri. Íslamiyet Öncesi Türk Destanlar (Ed. Saim Sakaoğlu, Ali Duymaz). İstanbul: Ötüken Neşriyat. 150-164.

Adıgüzel, S. (1997). Akbuzat, Zayatülek Ile Hıvhılvv ve Ahkak Kola Destanları Üzerine Bir Araştırma. Yüksek Lisans Tezi. Erzurum: Üniversitesi.

Atnur, G. (1996). Ural Batır Destanı Üzerine Bir Araştırma. Yüksek Lisans Tezi. Erzurum: Atatürk Üniversitesi.

Bars, M. E. (2014). Alp Tipi Kavramı Çerçevesinde Manas. Tarih Okulu Dergisi, XVII, 345-357.

Bayat, F. (2006). Oğuz Destan Dünyası Oğuznamelerin Tarihî, Mitolojik Kökenleri ve Teşekkülü. İstanbul: Ötüken Neşriyat.

Bekki, S. (2011). Bazı Halk Anlatıları ve Dinî Metinlere Göre Kahramanın Mucizevi (Babasız) Doğumu. Türk Kültürü ve Hacı Bektaş Veli Araştırma Dergisi, 58, 111130.

Çobanoğlu, Ö. (2007). Türk Dünyası Epik Destan Geleneği. Ankara: Akçağ Yayınları.

Ekici, M. (2004). Türk Dünyasında Köroğlu. Ankara: Akçağ Yayınları.

Ergin, M. (1997). Dede Korkut Kitabı I-II. Ankara: Türk Dil Kurumu Yayınları.

Kalafat, Y. (2003). Edige Destanında Olağanüstü Tipler. Selçuk Üniversitesi Türkiyat Araştırmaları Dergisi. 13, 345-352.

Kalkan, A. (2016). Türk Destanlarında Kahramanın Olağanüstü Doğumu. Türk Dünyast, 42, 27-47.
Kara Düzgün, Ü. (2007). Başkurt Destanlarının Tipolojisi. Doktora Tezi. Ankara: Gazi Üniversitesi.

Karatay, O., \& Aygün, E. (2012). Alplar ve Elfler: Türk ve İskandinav Dünyalarında Kahramanlık Olgusu. Karadeniz Araştırmalarl, 33, 1-12.

Kayabaşı, R. G. (2016). Anadolu Sahası Masallarında Kahramanın Doğumu ve Kahraman Olma Süreci. Türk Kültürü ve Hacı Bektaş Veli Araştırma Dergisi, 79, 129 142.

Kur'an-ı Kerim Meali (Hzl. Halil Altuntaş, Muzaffer Şahin). (2011). Ankara: Diyanet İşleri Başkanlığı.

Oh, E.. (2011). Cumong (Kore) ve Alpamış (Özbek) Destanlarında Kahramanın Doğuşu Hakkında Psikoanalitik Bir Değerlendirme. Folklor/Edebiyat, 67, 157-164.

Ögel, B. (1998). Türk Mitolojisi I (Kaynaklarl ve Açıklamaları ile Destanlar). Ankara: Türk Tarih Kurumu Yayınları.

Ögel, B. (2006). Türk Mitolojisi II (Kaynaklarl ve Açıklamaları ile Destanlar). Ankara, Türk Tarih Kurumu Yayınları.

Öztürk, G. (2001). Edige Batır Destanı'nın Başkurt Versiyonu (Inceleme-Metin-Transkripsiyonlu MetinÇeviri-Dizin). Doktora Tezi. İstanbul: Marmara Üniversitesi.

Pala, İ. (1995). Ansiklopedik Divan Şiiri Sözlüğ̈̈. Ankara: Akçağ Yayınları.

Raglan, L. (1998). Geleneksel Kahraman (Çev. Metin Ekici). Millî Folklor, 37: 126-138.

Sever, M. (2011). Köroğlu Destanı'nda (Azerbaycan Kolu) Kahraman ve Karşı Kahraman Tipleri. Gazi Akademik Bakış, 8, 195-202.

Suleymanov, A., İbrahimov, G., \& Ergun, M., (Hzl.). (2014b). Başkurt Destanları II Sosyal Hayatı Anlatan Destanlar. Ankara: Türk Dil Kurumu Yayınları.

Suleymanov, A., İbrahimov, G., \& Ergun, M., (Hzl.). (2014c). Başkurt Destanları III Beyler Hanlar Zamanını Anlatan Destanlar. Ankara: Türk Dil Kurumu Yayınları.

Suleymanov, A., İbrahimov, G., \& Ergun, M., (Hzl.). (2014a). Başkurt Destanlarl I Mitolojik Destanlar. Ankara: Türk Dil Kurumu Yayınları.

Suleymanov, A., İbrahimov, G., \& Ergun, M., (Hzl.). (2014d). Başkurt Destanlarl IV Tarihî Destanlar Kahramanlar Hakkında Destanlar Ozanlar. Ankara: Türk Dil Kurumu Yayınları.

Yıldırım, D. (1998). Türk Bitiği. Ankara: Akçağ Yayınları.

Yıldız, N. (2009). Türk Destanlarında "Çocuksuzluk”. Millî Folklor, 82, 76-88. 